\title{
A PRODUÇÃO DOS RESÍDUOS SÓLIDOS URBANOS: OS PERSISTENTES DESAFIOS SOCIOAMBIENTAIS PARA A GESTÃO PÚBLICA
}

\author{
Waldir da Silva Filho* \\ Frederico Fonseca da Silva** \\ José Carlos de Jesus Lopes*** \\ Paula da Silva Santos****
}

RESUMO: A preocupação com a gestão dos resíduos sólidos urbanos (RSU) começou a se tornar relevante à medida que a crescente população urbana começou a aumentar o nível de consumo e, consequentemente, a crescente necessidade de descarte, de forma ecologicamente correta, em espaços urbanos cada vez mais aglomerados. De forma complementar, o impacto ambiental provocado pelo descarte indevido dos RSU, ao longo de décadas, nas áreas urbanas, passou a se tornar objeto de preocupação não apenas da gestão pública municipal, mas, igualmente, de toda a sociedade brasileira. Os órgãos públicos, legalmente, responsáveis pela gestão dos RSU, por mais esforços técnicos, financeiros e políticos empregados na minimização dos conflitos gerados, parecem conviver com crescentes e complexos desafios socioambientais. Assim, o objetivo geral desta pesquisa é analisar os desafios da administração pública, com relação à gestão dos RSU, na região metropolitana de Curitiba (RMC), tendo como locus dois aterros sanitários construídos. Por conta da metodologia empregada, evidenciou-se que o problema da gestão dos RSU é complexo, em escala global e local. Conclui-se que ainda há dificuldades dos municípios brasileiros de se adequarem à lei $\mathrm{n}^{0} 12.305 / 10$, que impôs diferentes prazos legais para a construção de aterros sanitários em todos os municípios. Mesmo com alguns avanços, ainda restam muitos desafios socioambientais a serem superados, tanto pelos gestores públicos, quanto pela sociedade contemporânea.

PALAVRAS-CHAVE: Gestão pública; Sustentabilidade; Resíduos sólidos urbanos; Manejos tecnológicos; Aterros sanitários.

Discente do Curso Superior de Gestão Pública do Instituto Federal do Paraná (IFPR), Brasil.

** Docente e Pesquisador do Instituto Federal do Paraná (IFPR). Doutor em Irrigação e Meio ambiente pela UEM, Brasil.

*** Docente e Pesquisador da Universidade Federal do Mato Grosso do Sul (UFMS). Doutor em Meio Ambiente e Desenvolvimento, pela Universidade Federal do Paraná (UFPR), Brasil.

**** Discente do Programa de Pós-graduação em Administração, Curso de Mestrado em Administração, pela Universidade Federal de Mato Grosso do Sul (UFMS), Brasil. 


\title{
THE PRODUCTION OF URBAN SOLID WASTES: PERSISTING SOCIAL AND ENVIRONMENTAL CHALLENGES FOR PUBLIC ADMINISTRATION
}

\begin{abstract}
Concern on urban solid wastes (USW) became relevant as the increasing urban population increased its consumption level and the consequent need for disposal of wastes within a correct ecological stance in urban spaces. Further, the environmental impact caused by incorrect disposal of USW became a concern for Brazilian public management and for society as a whole. Although the public departments responsible for USW used all technical, financial and political efforts to minimize the conflicts generated, social and environmental challenges are on the increase. Current research analyzes the efforts of the public administration on USW in the metropolitan region of Curitiba focusing on two sanitary landfills. USW management is highly complex on global and local scales. Results show that Brazilian municipalities experience great difficulties in complying with Law 12.305/2010, imposing deadlines for the construction of landfills in all municipalities. Although great progress has been achieved, several social and environmental challenges have to be overcome by public administrations and by society.
\end{abstract}

KEY WORDS: Public administration; Sustainability; Urban solid wastes; Technological management; Sanitary landfills.

\section{INTRODUÇÃO}

A situação-problema dos resíduos sólidos urbanos (RSU) é reconhecida como um fenômeno social urbano, de alta complexidade, que se opera em escala global, mas com consequências locais. A gênese desta problemática guarda relação com o crescimento concentrado da população em espaços urbanos, associado ao padrão de produção e consumo contemporâneo, identificado como insustentável. Como o processo de urbanização e o crescimento populacional tende a continuar a elevar-se, em função da tendência do crescimento econômico global e de maior expectativa de vida da população mundial, projeta-se que milhões de pessoas serão servidas por lixões, principalmente nas periferias das economias em desenvolvimento e das regiões subdesenvolvidas.

Segundo Steiner e Newman (2015), os principais lixões hoje existentes no 
mundo estão localizados nos continentes da África, Ásia e América Latina/Caraíbas, além de mais dois na Europa. Para eles, os 50 maiores lixões, desigualmente distribuídos ao redor do planeta Terra, afetam a vida diária de 64 milhões de pessoas, uma população do tamanho da França. O Internacional Solid Waste Association (ISWA, 2015), além de apresentar dados alarmantes sobre a produção de RSU, adverte sobre o estilo de vida insustentável para todo o planeta. Os lixões, que são considerados como problemas complexos locais dos ecossistemas urbanos, recebem cerca de $40 \%$ dos resíduos sólidos produzidos no mundo e que atendem cerca de 3,5 a 4 bilhões de pessoas.

Ainda de acordo com ISWA, esta produção é constituída por uma diversidade de resíduos que são destinados aos ecossistemas urbanos, tais como resíduos urbanos, industriais, de construção civil, da saúde, eletrônicos, dentre outros elementos perigosos ao ser humano e aos animais e altamente poluidores, que em conjunto ou em separados causam vários danos à saúde das populações vulneráveis, que sobrevivem e moram no entorno dos lixões. No entanto, não é somente no ambiente urbano que os resíduos sólidos estão presentes. De acordo com Moore (2014, p. 33), os oceanos, por sua vez, também podem estar se transformando em um imenso depósito de lixo. Ele relata a sua preocupação do lixo de origem humana, que aqui merece destaque:

Acabo de regressar com uma equipe de cientistas de seis semanas no mar realizando pesquisas na Grande Mancha de Lixo do Pacífico - uma das cinco grandes porções de lixo flutuando nos oceanos norte e ao sul do Equador na latitude de nossos grandes desertos terrestres. Apesar de ter sido minha $10^{\circ}$ viagem para a área, eu estava completamente chocado ao ver o enorme aumento da quantidade de resíduos de plástico desde a minha última viagem em 2009. Os plásticos de todos os tipos, desde escovas de dente a pneus para fragmentos não identificáveis numerosos demais para contar passaram flutuando pelo nosso navio de investigação marinha Alguita por centenas de milhas sem fim.

A problemática dos lixões se faz presente aqui no Brasil que, quer seja pelo seu tamanho continental associado ao estilo de vida da sociedade contemporânea e fragilidades identificadas nas políticas públicas, torna-o o terceiro maior produtor de resíduos sólidos do planeta; apesar de estar abaixo da média mundial, em se 
tratando da produção diária de quilo de lixo por pessoa (IPEA, 2012). Ainda de acordo com ISWA, o Brasil tinha 2.906 lixões distribuídos por 2.810 municípios e que, legalmente, deveriam ser erradicados em 2014, conforme determina a lei $\mathrm{n}^{\mathrm{o}}$ 12.305/2010, normativa legal que disciplina o Plano Nacional de Resíduos Sólidos PNRS (BRASIL, 2010a).

Com relação ao prazo legal estipulado, Salomão (2015) explica que esse foi prorrogado, de forma diferenciada, pelo senado federal, devido a um projeto de lei, em que, a relatora apresentou como justificativa, que a maior parte dos municípios brasileiros não possui quadros técnicos e gestores públicos qualificados, nem recursos financeiros, para o cumprimento do prazo determinado pela mesma lei. De acordo com Canto (2015), as capitais brasileiras e os principais municípios das regiões metropolitanas terão até 31 de julho de 2018, para acabar com os lixões. Os municípios de fronteira e os que contam com mais de 100 mil habitantes, com base no Censo de 2010, terão um ano a mais para implementar os aterros sanitários. As cidades que têm entre 50 e 100 mil habitantes terão prazo até 31 de julho de 2020. Já o prazo para os municípios com menos de 50 mil habitantes será até 31 de julho de 2021.

Tais providências legais demonstram que a problemática dos RSU, assim como tantas outras situações que envolvem a sociedade urbana e as populações vulneráveis pressionam a gestão pública por ações e decisões mais eficazes e sustentáveis, decisões que não são fáceis de serem tomadas, uma vez que a gestão dos RSU envolve questões, além das ambientais, sociais, econômicas, políticas, culturais e legais, pois como enfatiza Waldman (2013, p. 1),

o lixo possui uma interface política, que se revela toda vez que se coloca debate sobre sua destinação, gestão, discriminação de responsabilidades, encaminhamento das normatizações e, sumamente, a aplicação das leis. Nessa ponderação, não deixa de ser significativo que a Lei $\mathrm{n}^{\mathrm{0}}$ 12.305, que justamente instituiu o PNRS, tenha demorado 19 anos para ser sancionada, demonstração evidente de conflitos entre grupos de interesse e de divergências quanto à regulamentação da gestão dos rejeitos.

É por conta desta situação-problema colocada que se estabelece o objetivo geral desta pesquisa que foi analisar os desafios da administração pública, com relação 
à gestão dos RSU, na região metropolitana de Curitiba (RMC). Especificamente, foi feita uma análise comparativa entre os dois modelos de gestão aplicada em cada ecossistema sob os quais foram construídos os dois aterros sanitários, que tratam e dão disposições finais aos RSU gerados na RMC.

Assim sendo, o locus deste estudo foram o aterro sanitário da Caximba e o aterro sanitário da Fazenda Rio Grande, respectivamente, ambos construídos na RMC, dado o esgotamento da resiliência ecológica do primeiro.

\section{PROCEDIMENTOS METODOLÓGICOS}

$\mathrm{Na}$ busca de compreender os fenômenos estudados nesta investigação científica, delinearam-se os procedimentos metodológicos, como bem ensinam Einsenhardt (1989), Creswell (2000), Gil (2010) e Marconi e Lakatos (2011 e 2013). Os objetivos da pesquisa combinam a exploratória, com a descritiva. Com relação aos procedimentos de levantamento de coletas de dados, como bem ensina Gil (2010), adotou-se o Estudo de Caso, sendo os locus da pesquisa dois aterros sanitários construídos na RMC, o aterro sanitário da Caximba e o aterro sanitário de Fazenda Rio Grande, ambos com o intuito de recolher daqueles ecossistemas informações e conhecimentos, por meio de um processo de observações, conforme instruem Cervo, Bervian e Silva (2007).

Os procedimentos dos dados coletados são primários e fortemente secundários; estes últimos referenciados por levantamentos bibliográfico e documental, complementados por entrevistas semiestruturadas presenciais e observações, quando das visitas técnicas no aterro sanitário da Caximba e no aterro sanitário de Fazenda Rio Grande, nos meses de janeiro, fevereiro e março de 2016.

Em ambas as visitas, foi possível aplicar entrevistas semiestruturas com os gestores públicos responsáveis pelo gerenciamento técnico dos dois ecossistemas. Por fim, adotou-se dentre as técnicas disponíveis de análises de dados, a qualitativa, uma vez que a temática envolve a pesquisa social aplicada, na qual foi possível compreender a temática por meio dos arranjos tecnológicos construídos nos dois aterros sanitários pesquisados, bem como a análise dos tomadores de decisões 
responsáveis pela gestão pública do tratamento e disposição final dos RSU na RMC. Este conjunto de ações metodológicas permitiu alcançar os objetivos propostos na parte introdutória, cujos resultados e discussões apresentadas estão amparados pelo arcabouço teórico, a seguir.

\section{FUNDAMENTAÇÂO TEÓRICA}

\subsection{LEI NACIONAL DE RESÍDUOS SÓLIDOS (Lei nº 12.305/2010)}

A lei $n^{0} 12.305 / 2010$, que institui o PNRS e o seu decreto $n^{0} 7.404 / 2010$, que regulamenta a mesma lei, disciplinam e normatizam para os Estados Federativos em conjunto com os municípios integrantes, a gestão ambiental proativa e inovadora, com diretrizes estruturantes compartilhadas, com forma de gestão participativa. A inovação institucional, social e política estão no destaque as corresponsabilidades dadas aos atores sociais envolvidos (BRASIL, 2010a e 2010b). Conforme relatam Jardim et al. (2012), a citada lei e respectivo decreto ensejam a proposta de vencer o atraso e promover o aperfeiçoamento contínuo da gestão dos RSU nos ecossistemas locais; desta vez, envolvendo os poderes públicos estaduais e municipais, a fim de criar um modelo de planejamento de gestão integrada, com a possível parceria com o setor empresarial. Sob esta ótica, a PNRS, no seu art. $4^{\circ}$,

Reúne o conjunto de princípios, objetivos, instrumentos, diretrizes, metas e ações adotadas pelo Governo Federal, isoladamente ou em regime de cooperação com Estados, Distrito Federal, Municípios ou particulares, com vistas à gestão integrada e ao gerenciamento ambientalmente adequado dos resíduos sólidos (BRASIL, 2010a).

Novamente conforme Jardim et al. (2012), o texto legal declara a necessidade de cooperação entre as diferentes esferas do poder público, o empresarial, e demais atores sociais, destacando entre seus objetivos, a articulação entre as diferentes esferas do poder público, e destas com o setor empresarial, com vistas à cooperação técnica e financeira para a gestão integrada dos RSU. A referida lei ainda define as corresponsabilidades entre os Estados Federativos e os municípios em seus planos 
de gestão de resíduos que devem prever metas de reutilização e reciclagem com vistas a reduzir a quantidade de resíduos e rejeitos produzidos pela sociedade e encaminhados para disposição final, social e ambientalmente adequada (art. 17, III e art. 19, XIV).

A princípio, a Associação Brasileira de Normas Técnicas (ABNT), por meio do material intitulado NBR 10004/2004 (BRASIL, 2004) classifica os resíduos sólidos quanto aos seus potenciais ao meio ambiente e à saúde pública, para que possam ser gerenciados adequadamente. E, em se tratando de resíduos sólidos, a norma define resíduos como

Resíduos nos estados sólidos e semissólido, que resultam de atividades de origem industrial, doméstica, hospitalar, comercial, agrícola, de serviços e de varrição. Ficam incluídos nesta definição os lodos provenientes de sistemas de tratamento de água aqueles gerados em equipamentos e instalações de controle de poluição, bem como determinados líquidos cujas particularidades tornem inviável o seu lançamento na rede pública de esgotos ou corpos de água, ou exijam para isso soluções técnica e economicamente inviáveis em face à melhor tecnologia disponível (BRASIL, 2004, p. 2).

Com relação à classificação desses resíduos, no que diz respeito à periculosidade para a NBR - ABNT 10004/2004 (BRASIL, 2004, p. 3), são:

1) Classe 1 (Perigosos): apresentam risco à saúde pública ou ao meio ambiente, caracterizando-se por possuir uma ou mais das seguintes propriedades: inflamabilidade, corrosividade, reatividade, toxicidade e patogenicidade;

2) Classe ll (Não perigosos): É subdividido em não inerte e inerte;

3) Classe II A (Não inertes): Aqueles que não se enquadram nas classificações de resíduos classe I e classe II B. Podem ter propriedades como: combustibilidade, biodegradabilidade ou solubilidade.

4) Classe II B (Inertes): Quaisquer resíduos que, quando amostrados de uma forma representativa, segundo a ABNT NBR 10007, e submetidos a um contato dinâmico e estático com água destilada ou desionizada, à temperatura ambiente, conforme ABNT NBR 10006, não tiverem nenhum de seus constituintes solubilizados a concentrações superiores aos padrões de potabilidade de água, excetuando-se aspecto, cor, turbidez, dureza e sabor, conforme anexo G.

Conforme aponta Lopes (2007), no Brasil, as técnicas mais empregadas para 
o tratamento e disposição final dos resíduos são os lixões, aterros controlados e aterros sanitários. Verificam-se algumas experiências de Usinas de Tratamento de Resíduos (UTR), empreendimento que se utiliza das técnicas de triagem, de forma integrada pelo processo de coleta seletiva, de compostagem e/ou reciclagem.

De acordo com o Phillip Jr (2005), os lixões são considerados formas ou locais de disposição final e tratamento impróprios do ponto de vista social, sanitário e ecológico, pois no conjunto propicia a propagação de vetores e o surgimento de doenças em seres humanos e nos animais, além de causar a poluição atmosférica e as contaminações nos solos e nos recursos naturais. Aterro controlado, como explica Bidone e Povinelli (1999), é uma maneira de disposição final de resíduos sólidos urbanos no solo, na qual, as prevenções tecnológicas exaustivas adotadas durante o incremento do aterro, aumentam a segurança do local, minimizando os riscos de impactos à saúde pública e ao meio ambiente.

O aterro sanitário incide de uma técnica de disposição do lixo, baseada em critérios de engenharia e normas operacionais particulares, que permite a confinação segura em termos de controle da poluição ambiental e proteção à saúde pública, conforme aponta o IBGE (2015). A gestão integrada de RSU tem sido apontada como uma alternativa estratégica para amenizar os impactos ambientais e à saúde pública. Ela poderá ser administrativa por meio de um consócio intermunicipal ou até mesmo uma UTR (LOPES, 2007). O mesmo autor ainda faz um alerta que muitos aterros controlados no país são denominados politicamente de aterros sanitários, contudo ao fazer um diagnóstico do modus operanti, das técnicas de tratamento e disposição dos RSU, bem como a presença de adultos e crianças sobrevivendo daquele ambiente, vê-se claramente que ainda tem mais características de lixões aterrados, do que o aterro sanitário desejável.

\subsection{A EVOLUÇÃO DA GESTÃO PÚBLICA EM CURITIBA, COM RELAÇÃO AO TRATA- MENTO E DISPOSIÇÃO FINAL DOS RSU}

A gestão dos RSU, em Curitiba, tem início no século XIX, quando o então presidente da província do Paraná, João José Pedrosa, já havia percebido as ruas muito sujas, evidenciando a falta de higiene e a ineficiência dos serviços de limpeza 
pública, conforme o enunciado de seu relatório na época. A proibição do despejo de resíduos, em vias públicas, teria previsão de acontecer, apenas no final do século XIX e início do XX, conforme relata Gaieski (1991). O primeiro lixão da cidade foi assentado em um terreno vago. De acordo com a prefeitura de Curitiba (2016), entre 1941 e 1943, o urbanista francês Alfred Agache trabalhou diretamente com técnicos da prefeitura local colocando em prática todos os seus preceitos no estudo de um centro urbano.

Segundo o que consta no Plano Municipal de Controle Ambiental e Desenvolvimento Sustentável (PREFEITURA DE CURITIBA, 2008), o plano criado por Agache, que depois veio a receber o seu nome (Plano Agache) tinha como prioridades o saneamento e o tráfego urbano da capital, como também a arborização, revitalização de praças e criação de parques onde, mesmo o plano não sendo implantado em sua totalidade, veio a nortear muitas das ações da prefeitura nas duas décadas seguintes à sua concepção. A lei municipal no 699/1953 passa a ser empregada como adoção de um novo código de posturas (PREFEITURA DE CURITIBA, 2004), o qual foi fundamental, tornando-se um marco na incipiente legislação ambiental da época que, em seu a Art. 747 proibia, sob pena de multa, jogar lixo de qualquer espécie nas vias públicas ou outros logradouros.

No ano de 1964 surge o primeiro aterro controlado, construído no bairro Lamenha Pequena (RIBEIRO, 2014) que, desde novembro de 2012, passou a ser monitorado ambientalmente, por meio de análises laboratoriais do lixiviado, das águas subterrâneas e do corpo receptor (RIBEIRO, 2014 e FRUET, 2015). De acordo com Oliveira (2007), o aterro sanitário de Curitiba, localizado no bairro da Caximba, na região Sul do município de Curitiba - passou a ser identificado como aterro sanitário da Caximba - teve seu início operacional, em 20 de novembro de 1989, para onde eram destinados os RSU de Curitiba e dos demais municípios-membros da RMC para tratamento e disposição final.

\subsection{A VIDA ÚTIL PROLONGADA DO ATERRO SANITÁRIO DA CAXIMBA, POR CON- TA DAS FORÇAS POLIITICAS}

As pesquisas de Oliveira (2007) apontam que o aterro sanitário da Caximba 
foi construído, consolidado, estendido, esgotado e superada a resiliência ambiental, em três fases distintas, pela administração pública, em diversos governos, descritas a seguir:

Fase I - o projeto original do aterro, com $2.920 .000 \mathrm{~m}^{3}$ de volume disponível, foi calculado prevendo 11 anos e cinco meses de vida útil. Alguns programas municipais como o Lixo que Não é Lixo e o Câmbio Verde possibilitaram o aumento de vida útil da Fase I, que operou desde a sua inauguração até outubro de 2002. Posteriormente, houve sobreposições ao maciço da Fase I, que ocorreram nos períodos de julho de 2005 a novembro de 2005, abril de 2006 e fevereiro de 2010 a outubro de 2010 (PREFEITURA DE CURITIBA, 2015a);

Fase II - no ano de 2002, executou-se uma ampliação do aterro, em caráter emergencial. Esta fase começou a receber resíduos, em novembro de 2002, e operou até o mês de abril de 2004. Ou seja, uma fase de ampliação programada, mas contida dentro da Fase I em razão dos programas estabelecidos; e,

Fase III - as obras para implantação dessa fase foram iniciadas em dezembro de 2003, após a desapropriação de terrenos vizinhos. Esta fase iniciou sua operação, em maio de 2004, recebendo resíduos até junho de 2005. Voltou a receber resíduos no período compreendido entre dezembro de 2005 e março de 2006; e, depois, no período de maio de 2006 a janeiro de 2010.

Ao longo da vida útil, o aterro sanitário da Caximba recebeu, oficialmente, um total de 12.133.794,80 toneladas de RSU. Com uma área total de terreno de 1.015.000 $\mathrm{m}^{2}$, a área útil destinada à disposição de lixo foi de $439.540 \mathrm{~m}^{2}$, correspondendo a 34,4\% da área total do empreendimento (PREFEITURA MUNICIPAL DE CURITIBA, 2014).

\section{RESULTADOS E DISCUSSÃO}

\subsection{VISITA TÉCNICA AO ATERRO SANITÁRIO DA CAXIMBA}

Antes de entrar no mérito da visita ao aterro sanitário da Caximba, vale ressaltar algumas das observações feitas por Lopes (2007, p 181),

mesmo diante dos conflitos socioambientais gerados na gestão dos resíduos sólidos urbanos na RMC, é possível compreender que o 
manejo tecnológico implantado no aterro sanitário da Caximba está atendendo às exigências técnicas legais e minimizando, pelo menos no presente, a questão do tratamento e disposição final do lixo urbano gerado pelos municípios usuários.

De acordo com Agência de Notícias da Prefeitura Municipal de Curitiba (2013), desde o seu fechamento, em 31/10/2010, o aterro sanitário da Caximba conta com o trabalho diário de, aproximadamente, 20 servidores, o que garante a manutenção de equipamentos instalados, entre eles, os sistemas de drenagem de águas pluviais, da estabilidade do aterro sanitário, da drenagem de gases e de tratamento de efluente, além de toda a infraestrutura e acesso à circulação (PARANAEXTRA, 2013). Em entrevista em uma das visitas ao extinto aterro da Caximba, Koch (2016), do Departamento de Limpeza Pública, da Secretaria do Meio Ambiente de Curitiba - SMMA, relatou que ainda é possível ver a movimentação dos servidores por toda a área do aterro, nas mais diversas funções, ratificando assim as informações descritas no parágrafo anterior.

Ainda durante a mesma visita, verificou-se a existência de 14 poços piezométricos que tem por finalidade o monitoramento das águas do lençol freático feito mensalmente, localizados em pontos específicos respeitando o fluxo subsuperficial da água abrangendo toda a área do aterro sanitário. Ainda no local, foi possível observar, a cobertura de toda a área por uma gramínea ali cultivada com o objetivo de auxiliar na manutenção da conservação solo do aterro sanitário, bem como a disposição de várias chaminés por toda a área onde é expelido o gás metano, proveniente da decomposição biológica da matéria orgânica ali aterrada.

Com relação ao gás metano, cabe ressaltar aqui, um estudo que foi realizado em 2005, por Silva et al. (2009). Nele, o aterro sanitário da Caximba teria os requisitos necessários para a implantação de um projeto de energia renovável, cuja tecnologia aplicada seria do Ciclo Otto, que é basicamente composto de motores de combustão interna ou turbinas a vapor, para a Usina Termelétrica da Caximba. Quanto ao potencial de créditos de carbono em 2005, ainda no mesmo estudo, eram de 389.540 ton. $/ \mathrm{CO}_{2}$ eq ; em 2010, de 584.310 toneladas/ $\mathrm{CO}_{2}$ eq; e, em 2015, de 77.908 toneladas $/ \mathrm{CO}_{2}$ eq.

5 TON/CO eq - toneladas de carbono equivalente. Estes valores são calculados a partir da relação do cálculo da tonelada de $\mathrm{CO}_{2}$ equivalente que não é emitida na atmosfera, geram-se 21 créditos de carbono, pois o metano é 21 vezes mais poluente que o $\mathrm{CO}_{2}$. 
Esse estudo comprova, que de alguma forma, poderia ter sido aplicada uma gestão pública ou privada, ou até mesmo em parceria público-privada, para aproveitar economicamente o gás, ao obter os créditos de carbono derivados daquele ecossistema, mas que por algum motivo, os gestores públicos não atentaram, estrategicamente, para essa oportunidade que trariam benefícios econômicos e sociais. Contudo, conforme pôde ser visto, in loco, no contorno da área estudada, a existência de uma boa interface de conservação entre solo protegido combinada com as áreas nativas remanescentes, uma coordenação técnica sustentável.

Ainda, conforme a entrevista, em se tratando das águas provenientes da chuva, foram construídas canaletas de concreto para drenagem da água pluvial, que se interligam em vários ramais que circundam toda a área do aterro sanitário com a destinação final no rio Iguaçu. Esse procedimento evita o acúmulo de água no subsolo em contato com o lixo aterrado, tomando assim um caminho diferente do líquido percolado proveniente da decomposição remanescente dos resíduos sólidos orgânicos ali ainda existentes. Em se tratando ainda do chorume, a entrevistada responsável pela gestão ecológica daquele ecossistema ressalta a importância de outras canaletas de concreto para a drenagem deste líquido que, por sua vez, tem como destinação os tanques de equalização.

Nesses tanques é feito um tratamento químico do líquido percolado que, segundo Cardoso (2016), de um modo geral em sua constituição se encontram as substâncias orgânicas (carbono e nitrogênio) e materiais inorgânicos (basicamente: mercúrio, cobre, chumbo, arsênio, cádmio, cobalto e cromo). Todos esses elementos químicos são provenientes de diferentes matérias decompostas pelo acúmulo de materiais sólidos encontrados no chorume do aterro sanitário da Caximba. De acordo com a engenheira ambiental e sanitária, apesar da adoção desse procedimento, fez-se necessária a utilização de cavas pré-existentes, oriundas de escavações antigas para a extração de areia, o que tornou possível a utilização do sistema de wetlands, uma reprodução de um ecossistema de organismos aquáticos em que a matéria orgânica restante no efluente do aterro é removida antes do lançamento no rio Iguaçu. Esse tratamento complementar consiste de três cavas, denominadas de banhados naturais, por onde passa o chorume que sai do tanque de equalização.

A concentração de poluentes vai diminuindo à medida que o sistema faz a absorção até chegar a um nível satisfatório para ser descartada no rio Iguaçu, 
conforme a resolução Cema no 94/2014 (CEMA, 2014) e a portaria IAP $n^{0}$ 259/2014 (IAP, 2014). Ou seja, a sobrevida da vegetação natural do ecossistema aquático existente nas wetlands que, segundo a engenheira, nesse processo, demonstra a redução de carga orgânica, estando apto a ser lançado ao corpo hídrico receptor, sem causar danos ao meio ambiente. Segundo Felix (2013), esse sistema auxiliar foi implantado em 2009 aumentando a eficiência do tratamento em até 80\%.

A preocupação com a diminuição do impacto ambiental vem de encontro com Maros e Brembatti (2015) quando levantam a questão de uma ação judicial proposta em 2001 pela Associação de Defesa do Meio Ambiente de Araucária - Amar, em que a justiça dá ganho de causa à associação, em que a prefeitura municipal de Curitiba deveria recuperar o rio Iguaçu e os lençóis freáticos de possíveis danos causados pelo aterro sanitário da Caximba. Ainda na mesma matéria destaca-se uma parceria firmada pela SMMA com as universidades, o que dá amparo a alguns projetos realizados. Esse procedimento vem corroborar com Lopes (2007), quando destacava como exigência aos atuais modelos de tratamento e disposição final dos RSU,

sejam amparados por manejos tecnológicos ecologicamente equilibrados, por plantas de tratamento mais limpas, com ganho de escala que, em conjunto com outras providências administrativas, fiscais e penais, venham a alcançar os objetivos e metas estabelecidos nos planos de gerenciamento aplicados sobre o lixo urbano. Tais ações são sugeridas, inclusive, por órgãos supranacionais que lidam com a problemática urbana ambiental, na qual o saneamento urbano está inserido (LOPES, 2007, p.38).

Por toda a área visitada foi possível visualizar a renovação do ecossistema, bem como a existência de uma variedade significativa de plantas e animais, e a existência de uma nascente d' água em harmonia com a engenharia construída para minimizar os impactos causados por um aterro sanitário. Concluindo a visita ao aterro sanitário da Caximba, cabe aqui uma reflexão e apresentações de possíveis alternativas do poder público, entendida, como desafios a serem superados. Trata-se de algumas reflexões críticas no sentido de otimizar o complexo processo de destinação e de tratamento dos resíduos sólidos urbanos, conforme propõe Waldman (2013, p. 4), 
O lixo domiciliar brasileiro, um dos grandes montantes na escala mundial, solicita um modelo de gestão que priorize a revisão dos processos geradores de resíduos, a começar pelos hábitos de consumo, e que, igualmente, tenha na reciclagem uma política propositiva de ponta. Dispensando essas estratégias, dificilmente o lixo domiciliar brasileiro deixará de ser o que é: uma questão polêmica por não se ajustar a uma gestão ótima dos resíduos.

Assim sendo, cabe ressaltar que, mesmo diante do acompanhamento técnico dos manejos ecologicamente arranjados, poucas pesquisas foram voltadas para as famílias que integram a população do entorno do "ex Caximba", bem como as políticas públicas que foram direcionadas àquela comunidade carente, derivadas das receitas tributárias coletadas nas taxas de lixo de Curitiba.

\subsection{VISITA TÉCNICA AO ATERRO SANITÁRIO DA FAZENDA RIO GRANDE (PR)}

Em final de 2010, entrou em funcionamento o Centro de Gerenciamento de Resíduos (CGR Iguaçu), localizado no bairro Santa Terezinha, em Fazenda Rio Grande (PR), município membro da RMC. Esse empreendimento ocupa uma área de 62 hectares dos 264,4966 existentes, em que os restantes, tornar-se-iam uma área de preservação permanente, sendo o empreendimento de responsabilidade da empresa Estre Ambiental S.A, com sede em São Paulo. O CGR Iguaçu recebe resíduos sólidos, Classe II, conforme NBR-ABNT 10004-2004, que são recolhidos pelos serviços municipais de Curitiba e dos demais municípios que integram a RMC, coleta regular, domiciliar, varrição de ruas e vias públicas. Tem também como destinação ao aterro os materiais provenientes de shopping centers, supermercados, lojas de departamentos e estabelecimentos comerciais da RMC.

Atualmente, o aterro sanitário recebe uma média de 2.500 toneladas/dia de resíduos sólidos, chegando a um quantitativo mensal de 75.000 toneladas/mês, conforme relata Andrades (2016). De acordo com a referida funcionária, é realizado pela equipe interna do aterro o controle operacional de toda a infraestrutura de saneamento, estação de tratamento do chorume, prevenção do assoreamento dos corpos hídricos superficiais e prevenção de emissão de ruídos. Contudo, a prevenção da poluição de águas superficiais e prevenção de emissão atmosférica são realizadas 
e monitoradas por empresas terceirizadas.

Durante a visita ao local, verificou-se a não utilização de wetlands, como ocorreu no extinto aterro da Caximba, pois, de acordo com a responsável, a estação de tratamento de chorume constitui em pré-tratamento: elevatória de lixiviado, peneiramento, sistema de flotação (DAF), tanque de equalização, tanque de neutralização, sistema de dosagem de produtos químicos. Por fim, segundo a responsável técnica, a empresa estaria implantando uma usina de biogás que tem previsão de conclusão em julho/2016. Inicialmente, a energia elétrica gerada será revertida para operação da estação de tratamento de chorume, mas a intenção é que o excedente seja vendido para a concessionária elétrica.

\subsection{PLANO DE GESTÃO INTEGRADA DE RESÍDUOS SÓLIDOS}

Em outubro de 2015, foi revisado o Plano de Gestão Integrado de Resíduos Sólido - PGIRS do município de Curitiba, instituído em dezembro de 2013, para atender aos seguintes objetivos:

a. Alinhar o Plano de Gestão Integrada de Resíduos Sólidos do Município às diretrizes, estratégias, metas, programas e ações definidos no Plano Nacional de Resíduos Sólidos, de agosto de 2012;

b. Compor o Plano Municipal de Saneamento Básico, conforme previsto no artigo 19 da Lei ${ }^{\circ} 11.445$, de 2007 , no que tange a limpeza urbana e manejo de resíduos sólidos; e,

c. Atender pré-requisito para acesso a recursos da União, destinados a empreendimentos e serviços relacionados à limpeza urbana e manejo de resíduos sólidos (PREFEITURA DE CURITIBA, 2013a).

Percebe-se que esses arranjos legais têm como meta corroborar com o enunciado no art. 16, da lei $n^{0} 12.305 / 2010$, que trata da elaboração de um Plano Estadual de Resíduos Sólidos - PERS, como condição para que os Estados tenham acesso a recursos financeiros da União destinados a empreendimentos e serviços relacionados à gestão de resíduos sólidos, como também, para serem beneficiados por incentivos ou financiamentos de entidades federais de crédito ou fomento para tal finalidade. Ainda no que se refere ao tratamento e destinação final de resíduos, o Município de Curitiba integra o Consórcio Intermunicipal para a Gestão Integrada 
de Resíduos Sólidos Urbanos (Conresol), criado com o objetivo de organizar e proceder ações e atividades para a gestão do sistema de tratamento e destinação final dos RSU.

Esta ação é regida sob a forma jurídica de associação pública, sem fins lucrativos, de acordo com as normas da lei $\mathrm{n}^{0} 11.107 / 2005$ (BRASIL, 2005), pela lei $\mathrm{n}^{\mathrm{O}}$ 11.445/2007 (BRASIL, 2007a) e pelo decreto $n^{\circ}$ 6.017/2007 (BRASIL, 2007b), bem como demais legislações pertinentes e pelo seu estatuto. Ficou definido que a coleta e o transporte dos resíduos domiciliares, públicos e de pequeno comércio, assim como pequenas quantidades de resíduos da construção civil são, em geral, de responsabilidade do órgão municipal gestor da limpeza pública. Já a coleta e o transporte dos resíduos de grandes geradores, como indústrias, comércios e categorias específicas, por exemplo, portos, aeroportos e atividades agrícolas, são de responsabilidade do gerador.

Em Curitiba, os serviços de coleta e transporte de resíduos sólidos domiciliares contemplam a coleta e transporte de resíduos úmidos (lixo comum) e resíduos secos (lixo reciclável). A coleta de resíduos secos (recicláveis) é ofertada porta a porta, por meio do Programa Lixo que não é Lixo, em pontos de troca do Programa Câmbio Verde, nas estações de sustentabilidade e ainda com o apoio à coleta informal, realizada pelos catadores de materiais recicláveis (PREFEITURA DE CURITIBA, 2013a). Mesmo considerando os esforços normativos que são institucionalizados para a coleta, disposição e tratamento dos resíduos sólidos produzidos pela sociedade ávida pelo consumo, nada se destaca em relação aos programas de incentivos da redução do consumo de bens duráveis e não duráveis, nada se destaca com relação à mudança da cultura do consumismo numa sociedade capitalista, tornando, desta forma, um desafio para a gestão pública.

Diante do exposto, há de se sobressair os desafios que os gestores públicos continuam a não enfrentar, possivelmente, na fonte da produção dos resíduos sólidos urbanos, que é o padrão de produção e de consumo escolhido e potencializada pela sociedade local e global. 


\section{CONSIDERAÇÕES FINAIS}

Relembrando, o objetivo geral desta pesquisa foi analisar os desafios da administração pública, com relação à gestão dos RSU, na RMC. Especificamente, foi feita uma análise comparativa entre os dois modelos de gestão aplicados em cada ecossistema sob os quais foram construídos os dois aterros sanitários, que tratam e dão disposições finais aos RSU, gerados na RMC. São eles, que serviram de locus deste estudo de caso, o aterro sanitário da Caximba e o aterro sanitário da Fazenda Rio Grande, respectivamente, ambos construídos na RMC, dado o esgotamento da resiliência ecológica do primeiro.

Por conta dos procedimentos metodológicos empregados, foi possível alcançar os objetivos propostos, inicialmente. Verificou-se que os dois aterros sanitários visitados, por mais que fossem construídos tecnicamente corretos, continuam sendo duas estruturas de engenharia com espaços naturais consideráveis sendo disponibilizados para o tratamento e disposição final dos RSU produzidos pela sociedade consumista da RMC. Ainda que se aplique toda a tecnologia disponível na manutenção dos aterros sanitários, há de se repensar seriamente sobre o consumo consciente, mesmo com o aproveitamento do potencial energético proveniente do resíduo. Trata-se, inegavelmente, ainda de algo que necessita de demanda política e tem um custo elevado, ou seja: o desafio de reduzir o consumo e o desperdício.

A lei $\mathrm{n}^{0} 12.305 / 2010$, por mais que tenha instituído o PNRS e o seu decreto $\mathrm{n}^{\mathrm{0}} 7.404 / 2010$, que regulamenta a mesma lei, não foram suficientes para fazer com que a administração pública cumprisse com o mando legal, quer seja por falta de recursos financeiros, quer seja por uma vontade política, quer seja pela fragilidade em resolver os conflitos socioambientais inerentes, já apontados por outras pesquisas, quer seja pela escassez de larga faixa de área tecnicamente viável para a construção de um novo aterro sanitário ou mesmo de uma usina de tratamento de resíduos, quer seja pela rejeição de determinadas classes sociais em não ter em seu entorno um empreendimento que reduz o valor imobiliário do entorno. $\mathrm{O}$ desafio legal ainda persiste.

De qualquer forma, quando se pensa na possibilidade da identificar novos modelos de gestão pública isolada ou de uma gestão pública-privada, já prevista 
na mesma lei, verifica-se ainda o desafio de possibilitar aos Estados federativos e aos municípios estabelecer uma gestão de parceria com consórcios intermunicipais, que operam dentro da lógica de uma empresa eficaz, que vise, o desempenho empresarial combinado com a filosofia da sustentabilidade dos ecossistemas urbanos. Por fim, ao longo desta pesquisa, verificou-se ainda que há vários desafios a serem superados, quer seja pelos gestores públicos que integram a administração pública, que legalmente são responsáveis pela gestão dos RSU, bem como pelas empresas produtoras de bens que encantam os clientes consumidores, ávidos por novos produtos, e que ambos deixam passivos socioambientais incalculáveis nos ecossistemas naturais.

Os consumidores não escapam de serem apontados como corresponsabilidades pela produção e da gestão dos RSU. Há a necessidade de cada consumidor reeducar-se para um consumo não exagerado, tornando-se, assim consumidores-cidadãos conscientes, o que significa outro desafio para esses atores. Diante do exposto, não se pode exigir apenas da administração pública uma eficiente gestão dos RSU, pois ela não é a única atora envolvida nesta problemática, muito embora ela tenha a sua parcela significante de responsabilidade, mas tal exigência deve alcançar a sociedade de consumo, que está contemporaneamente, amparada por um modelo societal. Um desafio e tanto. Que outras pesquisas possam investigar mais esses desafios, bem como as populações vulneráveis que vivem entorno desses ecossistemas, que apresentam uma frágil resiliência humana e ecológica.

\section{REFERÊNCIAS}

ABNT - Associação Brasileira de Normas Técnicas. NBR 10004:2004 de 31/05/2004. 3 definições - 3.1 resíduos sólidos. Disponível em: < http://www.videverde.com.br/ docs/NBR-n-10004-2004.pdf> . Acesso em: 11 fev. 2016.

ANDRADES, S. A. Estre Ambiental S.A - CGR Iguaçu. Entrevista realizada com a responsável técnica do empreendimento visitado. Fazenda Rio Grande (PR), março, 2016. 
BIDONE, F.R.A.; POVINELLI, J. Conceitos básicos de resíduos sólidos. São Carlos: EESC/USP, 1999.

BRASIL. Lei $\mathbf{n}^{\mathbf{0}} 11.445$ - Planalto. 2007a. Disponível em: <www.planalto.gov.br/ ccivil_03/_ato2007-2010/2007/lei/11445.htm>. Acesso em: 12.03.2016.

BRASIL. Decreto $\mathrm{n}^{0} 6017$ - Planalto. 2007b. Disponível no endereço eletrônico: <www.planalto.gov.br/ccivil_03/_ato2007-2010/.../decreto/d6017.htm>. Acesso em: 12.03.2016.

BRASIL. Lei $\mathrm{N}^{\mathrm{0}}$ 11.107, de 6 de abril de 2005. Disponível em: < http://www.planalto. gov.br/ccivil_03/_ato2004-2006/2005/lei/111107.htm>. Acesso em: 12.03.2016.

BRASIL. A Lei $\mathbf{n}^{\mathbf{0}}$ 12.305/10 - Política Nacional de Resíduos Sólidos. 2010a. Disponível em: <http://www.mma.gov.br/pol\%C3\%ADtica-de-res\%C3\%ADduoss\%C3\%B3lidos > . Acesso em: 12 mar. 2016.

BRASIL. Decreto No 7.404, de 23 de Dezembro de 2010. Presidência da República. 2010b. Disponível em: < http://www.planalto.gov.br/ccivil_03/_ato2007-2010/2010/ decreto/d7404.htm > . Acesso em: 12 mar. 2016.

BRASIL. Decreto $\mathbf{n}^{0} \mathbf{7 2 1 7}$ - Planalto. Disponível em: <www.planalto.gov.br/ ccivil_03/_ato2007-2010/.../decreto/D7217.htm > . Acesso em: 12 mar. 2016.

BRASIL. Política Nacional de Resíduos Sólidos completa 3 anos. 2013. Disponível em < http://www.brasil.gov.br/meio-ambiente/2013/08/politica-nacionalde-residuos-solidos-completa-3-anos > . Acesso em: 12 mar. 2016.

CANTO, R. Políitica Nacional do Eterno Adiamento. Disponível em: < http://www.envolverde. com.br/opiniao/colunistas2015/a-politica-de-residuos-solidos-deveria-ter-outro-nome-politicanacional-doeterno-adiamento/> . Acesso em: 12 mar. 2016.

CARDOSO, M. Chorume. INFOESCOLA. 2016. Disponível em: <http://www. infoescola.com/quimica/chorume/> . Acesso em: 18 fev. 2016. 
CEMA - Resolução CEMA no 94/2014. 2014. Disponível em: < http://www. rcambiental.com.br/Atos/ver/RESL-CEMA-PR-94-2014/>. Acesso: em 28 de março, 2016.

CERVO, A.L.; BERVIAN, P.A.; SILVA, R. Metodologia científica. 6. ed. São Paulo: Pearson Prentice Hall, 2007.

CRESWELL, J.W. Projeto de Pesquisa. Métodos qualitativo, quantitativo e misto. 2. ed. Porto Alegre, Artmed, 2000.

EINSENHARDT, K.M. Building theories from Case Study Research. Academy of Management. The Academy of Management Review, Oct 1989. Disponível em: https://books.google.com.br/books?hl=pt-BR\&l $\mathrm{r}=\& \mathrm{id}=5 \mathrm{~W} 6 \mathrm{WAs} 46 \mathrm{xecC} \& \mathrm{oi}=\mathrm{fnd} \& \mathrm{pg}=\mathrm{PA} 65 \& \mathrm{dq}=$ building + theories + from + case + study + research \&ots $=$ E0FuoDrVL\&sig $=$ Tf5 cwRBZ8qhM

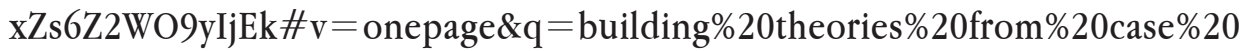
study\%20research\&f $=$ false $>$. Capturado em ago_2015.FÉLIX, R. Projeto inédito ajuda a dar vida ao aterro da Caximba. Jornal Gazeta do Povo. 2013.

FELIX, G. C. Análise da gestão de resíduos sólidos urbanos no Rio de Janeiro frente à política nacional de resíduos sólidos. 2013. Tese de Doutorado. Universidade Federal do Rio de Janeiro.

FRUET, G. Plano de Gestão Integrada de Resíduos Sólidos de Curitiba - PGIRS, 118 pag. Disponível em: <http://multimidia.curitiba.pr.gov.br/2010/00082071. pdf > . Acesso em: Curitiba - 2015.

GAIESKI, A.A. Curitiba o Gerenciamento dos Resíduos Sólidos Passado, Presente e Perspectivas. UFSC - Programa de Pós Graduação em Geografia. Dissertação de mestrado. Florianópolis (SC), 1991.

GIL, A.C. Como elaborar projetos de pesquisa. 5. ed. São Paulo: Atlas, 2010.

IAP - Instituto Ambiental do Paraná. Portaria IAP no 259/2014. 2014. Disponível em: <http://www.rcambiental.com.br/Atos/ver/PORT-IAP-PR-259-2014/>. Acesso em: 28. mar. 2016. 
IBGE - Instituto Brasileiro de Geografia e Estatística. População de Curitiba. 2015. Cidades. Disponível em: <http://cidades.ibge.gov.br/xtras/temas. php?codmun $=410690 \&$ idtema $=130>$. Acesso em: 10.02.2016.

IPEA - Instituto de Pesquisa Econômica Aplicada. Brasil precisa erradicar 2906 lixões até 2014. 2012. Disponível em: <http:/g1.globo.com/natureza/ noticia/2012/04/brasil-precisa-erradicar-2906-lixoes-ate-2014-afirma-estudo-do-ipea. html > . Acesso em: 10.02.2016.

ISWA - Internacional Solid Waste Association. WASTED HEALTH - the tragic case of dumpsites. This report has been prepared as a part of ISWA's Scientific and Technical Committee Work-Program 2014-2015.

JARDIM, A.; YOSHIDA, C.; MACHADO FILHO, J.V. Política Nacional, Gestão e Gerenciamento de Resíduos Sólidos - 342.151, exemplar 802236. Editora Manole, 2012.

LOPES, J.C.J. Resíduos Sólidos Urbanos: consensos, conflitos e desafios na gestão institucional da Região Metropolitana de Curitiba - Tese de Doutorado. UFPR-Curitiba, 2007.

MARCONI, M.A.; LAKATOS, E.M. Metodologia do Trabalho Científico. Procedimentos básicos, pesquisa bibliográfica, projeto e relatório, publicação e trabalhos científicos. 7. ed. São Paulo: Atlas, 2013.

MARCONI, M.A.; LAKATOS, E.M. Técnicas de pesquisa. Planejamento e execução de pesquisas, amostragens e técnicas de pesquisa, elaboração, análise e interpretação de dados. 7. ed. São Paulo: Atlas, 2011.

MAROS, A.; BREMBATTI, K. Justiça leva 14 anos para julgar poluição na Caximba. Jornal Gazeta do Povo. 14. set. 2015.

MOORE, C. Expedição giro do Pacífico Norte. 2014. Disponível em: http://www. algalita.org/. Acesso em: 10 fev. 2016.

OLIVEIRA, N.A.S. A produção e gerenciamento dos resíduos sólidos em Curitiba (PR) e as alternativas de contribuição com o meio ambiente. Revista Eletrônica 
Geografar, Curitiba, v.2, n.2, p.124-138, jul./dez. 2007.

PARANAEXTRA. Aterro da Caximba recupera biodiversidade e vira referência ambiental, 2013. Disponível em: <http://paranaextra.com.br/aterro-da-caximbarecupera-biodiversidade-e-vira-referencia-ambiental/> . Acesso em: 19 jan. 2016.

PHILIPPI JR, A. Saneamento, Saúde e Ambiente. Fundamentos para um desenvolvimento sustentável. Barueri, SP: Manole, 2005. (Coleção Ambiental; 2).

PREFEITURA DE CURITIBA. Conhecendo Curitiba - Centro Cívico. 2016. Disponível em: <http://www.curitiba.pr.gov.br/conhecendocuritiba/centrocivico $>$. Acesso em: 19 mar. 2016.

PREFEITURA DE CURITIBA. Cambio verde. 2015a. Disponível em: < http://www. curitiba.pr.gov.br/conteudo/cambio-verde-smma/344> . Acesso em 10 fev. 2016.

PREFEITURA DE CURITIBA. População da Região Metropolitana de Curitiba. Disponível em: < http://www.curitiba.pr.gov.br/conteudo/regiao-metropolitana-decuritiba/186>. Acesso em: 03 mar. 2016. 2015b.

PREFeITURA DE CuritiBa. Limpeza Pública, Aterro Sanitário de Curitiba. 2014. Disponível em: <http://www.curitiba.pr.gov.br/conteudo/aterro-sanitariosmma/454 > . Acesso em: 10 fev. 2016.

PREFEITURA DE CURITIBA. Secretaria Municipal do Meio Ambiente. Legislação Municipal. 2013a. Disponível em: <http://www.curitiba.pr.gov.br/conteudo/ legislacao-smma/347 >. Acesso em: 10 fev. 2016.

PREFEITURA DE CURITIBA. Plano municipal de saneamento de Curitiba. 2013b. Volume V - Gestão integrada de resíduos sólidos urbanos. Disponível em: < http:// multimidia.curitiba.pr.gov.br/2013/00142058.pdf> . Acesso em: 11 fev. 2016.

PREFEITURA DE CURITIBA. Plano Municipal de Controle Ambiental e Desenvolvimento Sustentável. Versão completa - V. 1. Junho/2008 - Prefeitura Municipal de Curitiba. Disponível em: <http://www.portalodm.com.br/ 
publicacao/401/plano-municipal-de-controle-ambiental-e-desenvolvimentosustentavel >. Acesso em 10 fev. 2016.

PREFEITURA DE CURITIBA. Leis municipais. Lei Ordinária 699/1953. Disponível em: < <https://eismunicipais.com.br/a/pr/c/curitiba/lei-ordinaria/1953/69/699/leiordinaria-n-699-1953-dispoe-sobre-o-codigo-de-posturas-e-obras-do-municipio-decuritiba-ficando-revogadas-as-leis-n-480-de-26-41917-lei-n-527-de-23-1-1919-lei-n579-de-24-12-1920-lei-n-630-de-2-5-1924-lei-n-642-de-5-11-1924-lei-n-717-de-4-111928-lei-n-769-de-27-5-1929-decreto-n-29-de-14-7-1934-decreto-n-27-de-13-8-1935decreto-n-28-de-13-8-1935-lei-n-50-de-25-1-1937-lei-n-76-de-26-10-1937-decretolei-n-8-de-5-4-1939-decreto-n-15-de-18-7-1939-decreto-n-19-de-3-8-1939-decretolei-n-9-de-27-10-1941-decreto-lei-n-20-de-15-1-1942-decreto-lei-n-21-de-15-1-1942decreto-lei-n-25-de-20-2-1942-decreto-lei-n-77-de-28-7-1943-lei-n-17-de-24-2-1946decreto-lei-n-146-de-9-9-1946-lei-n-57-de-3-6-1948-lei-n-105-de-2-8-1948-decreto-n287-de-3-10-1948-lei-n-217-de-19-9-1949-lei-n-305-a-de-10-1-1951-lei-n-475-de-6-51952-lei-n-674-de-13-6-1953 > . Acesso em: 10 fev. 2016.

RIBEIRO, I.L. Análise de risco a saúde humana por ingestão à água subterrânea - Aterro da Lamenha Pequena, Curitiba - PR. Monografia de Especialização em Análise Ambiental - UFPR, 2013. Disponível em: < http://dspace.c3sl.ufpr.br/ dspace/bitstream/handle/1884/40211/R\%20-\%20E\%20-\%20IAN\%20DE\%20LIMA\%20 RIBEIRO.pdf?sequence $=1 \&$ isAllowed $=\mathrm{y}>$. Acesso em: 10 fev. 2016.

SALOMÃO, L. Senado aprova prorrogar por 2 anos extinção de lixões, 2015. Disponível em: <http:/g1.globo.com/politica/noticia/2015/07/senado-aprovaprorrogar-por-2-anos-extincao-de-lixoes.html > . Acesso em: 10 fev. 2016.

SILVA, L.; CHRISTIAN, R.M.O.; JOSÉLIA, R.B.C.; VLÁDIA, R.F.S.; LUCIANO, B.A.H. A Cadeia de Biogás e a sustentabilidade local: uma análise socioeconômica ambiental da energia de resíduos sólidos urbanos do aterro da Caximba em Curitiba. Revista Innovare, v. 19, n. 34, 2009.

STEINER, A; NEWMAN, D. Global Waste Management Outlook (GWMO). 2015. Disponível em: <http://www.unep.org/ietc/Portals/136/Publications/Waste\%20 
Management/GWMO\%20report/GWMO\%20full\%20report.pdf>. Acesso em: 03 fev. 2016.

WALDMAN, M. Lixo Domiciliar Brasileiro: Modelos de Gestão e Impactos Ambientais. USP - Universidade de São Paulo, São Paulo, 2013. Disponível em: $<$ http://www.mw.pro.br/mw/geo_ecologia_paper_palestra_itanhaem.pdf $>$. Acesso em: 10 fev. 2016.

Recebido em: 06 de agosto de 2014 Aceito em: 13 de fevereiro de 2017 